\title{
Utah Library Association Annual Conference welcomes ACRL
}

\author{
Ry Sally M. Patrick \\ Conference Chair, Utah Library \\ Association Annual Conference
}

The Utah Library Association (ULA) will hold its annual conference April 13-15, 1992, concurrently with ACRL's 6th National Conference in Salt Lake City, April 12-14. ULA members welcome our ACRL colleagues and hope that the programming and exhibit opportunities from each association will enhance the experience for all participants.

ULA's conference theme is "Success Through Diversity." The conference programs will be held at the Doubletree Hotel and the exhibits will be in the ACRL exhibit area in the Salt Palace. The ULA exhibits will feature western regional publishers and a well-stocked combined book exhibit. The registration rate for ULA or ACRL members is $\$ 35$ (\$50 after March 13, 1992). The fee for individuals registering for both conferences is $\$ 25$ ( $\$ 40$ after March 13, 1992).

Please look over the details below and additional information in the January issue of C $\forall R L$ News, fill out the registration form on the next page, and send it in promptly. We look forward to seeing you!

\section{"Success through Diversity" conference highlights}

\section{Author functions}

Monday, April I3, luncheon with Gary Paulsen. Gary Paulsen, Newbery Honor Award winner for Hatchet and The Winter Room, is a favorite with juvenile and young adult librarians. $\mathrm{He}$ thrills readers of all ages with his exciting stories.

Tuesday, April 14, luncheon with Barbara Kingsolver. Projecting a new release this spring, award-winning writer Barbara Kingsolver has received international acclaim for her sensitivity to women. She is best known for her books The Bean Trees and Animal Dreams.

Tuesday, April 14, a gala evening with Tony Hillerman. Legendary author of rich tales of the desert Southwest, Tony Hillerman is releasing a new book soon entitled Mudhead
Kiva. It promises to be just as popular as his numerous other successes, including A Thief of Time. Join Mr. Hillerman for a reception and dinner as he discusses how the crafting of this novel was influenced by a river trip down the beautiful San Juan River in Southeastern Utah.

\section{Post-conferences}

The following post-conferences will be offered on April 15 at the Doubletree Hotel (you do not need to register for the ULA conference to attend the post-conference)

Here's how to C.O.P.E.-creating opportunities for personal empowerment given by Kaycee Hale, executive director of the Resource and Research Center of the Fashion Institute of Design \& Merchandising. This post-conference will cover personal and professional empowerment, coping skills for success into the 21 st century, stress reduction, problem-solving in the workplace, and managing change. She is a truly inspiring speaker.

Creativity: (What it is and how to use it) given by Susan Jurow, Office of Management Studies. This workshop is designed to improve library effectiveness through the application of creative problem-solving strategies tolibrary problems and concerns. It will assist individuals in making the best possible use of personal strengths in the development and implementation of new ideas.

Total quality management in government, or how to thrive on chaos and achieve TQM given by Roger Kirkham, president, American Training Alliance. This post-conference will cover the basic principles of Total Quality Management and implementation strategies which could be effective in public sector applications. Here is an opportunity to learn an overview of one of the most popular management topics of the decade. 


\section{Utah Library Association}

Annual Conference, April 13-15, 1992

Advance Registration

Doubletree Hotel and Salt Palace, Salt Lake City

Last Name

First Name

Middle Initial

Institution name

Mailing address

City

State

Zip

Daytime phone

Current membership: $\square$ ULA $\square$ ACRL $\square$ Non-member

(Registration cannot proceed without this information.)

\section{Conference registration fees}

\section{(check one)}

Full conference

$\square$ ULA or ACRL Member

$\square$ ULA/ACRL Joint Regis. (please include proof of registration for ACRL Conference)

○ Non-Member

Daily registration

○ ULA or ACRL Member

口 Non-Member

$\$ 35.00$ late registration (postmarked (postmarked by $3 / 13 / 92$ )

Conference Registration not necessary for individual events.

Meals \& entertainment (see Conference Highlights for details)

\section{Monday, April 13, 1992}

$\$ 50.00$

$\$ 40.00$

$\$ 75.00$

$\$ 30.00$

$\$ 40.00$

$\$$

amount

paid
Author luncheon, Gary Paulsen, $\$ 15.00 /$ ticket

Tuesday, April 14, 1992

$\square$ Author luncheon, Barbara Kingsolver, $\$ 15.00 /$ ticket

口. A gala evening with best selling author Tony Hillerman 6:00-7:00 p.m. Wine reception

7:00-9:30 p.m. Southwestern fare dinner \& book signing

For the evening, $\$ 35.00 /$ ticket

\section{Post-conferences}

Wednesday, April 15, 1992

8:00 a.m.-4:00 p.m. (Post-conference registration fees include lunch)

$\square$ Here's How to C.O.P.E., Kaycee Hale, $\$ 75.00$

$\square$ Creativity, Susan Jurow (limited registration), $\$ 75.00$

ㄱ Total Quality Management, Roger Kirkham, $\$ 75.00$

$\$$

$\$$

$\$$

$\$$

$\$$

Total amount enclosed

Make checks payable to: ULA 1992 Annual Conference

Refunds (minus $\$ 5.00$ handling fee) up to 2 weeks before conference

Send completed registration and payment to:

Utah Library Association, 2150 South 300 West, Suite 16, Salt Lake City. UT 84115. Att: Annual Conference Registration 